https://ejournal.uniska-kediri.ac.id/index.php/PROFICIENCY

\title{
THE TEACHING WRITING OF DESCRIPTIVE TEXT IN SPECIFIC CLASS OF THE SEVEN GRADE OF MTSN 2 KEDIRI
}

\author{
By: Damara Ilham Ramadhany, Agus Amroni
}

\begin{abstract}
This research was carried out to answer the 3 objectives of study. Those are: (1) the teaching process in 7C class (in the terms of curriculum, syllabus, lesson plan, method, and media), (2) the response student (in term dificulties, perception) and (3) the teacher solution (in the terms of Problem indication and problem solving). The design was descriptive qualitative. The reason of this study used descriptive qualitative because the teaching writing of descriptive text in specific class of MTsN 2 Kediri was so unique because teacher use blog as media to support learning activities. The research instruments were observation sheet, interview note/sheet, document, and field note. The data collecting method were observation, interview, documentation, and field note. The data analysis descriptively using data reduction, data display, verification, and the validity of triangulation. The findings were 1) The teaching process was had Syllabus, Lesson plan, method, and media, 2) The response of student towards the teaching and learning process writing class is good. 3) The problem solution done by teacher is always reminding and evaluating the mistakes made by student. Based on the findings above the teaching writing of descriptive text was good because teacher maximaly media and the other were also maximal and appropriate.
\end{abstract}

\section{INTRODUCTION}

Learning English as foreign language is a challenging process that many students encounter for the sake of surviving in the globalization era. The high demand on mastering English language to face the development of science and technology became one of reasons many students force themselves to learn. English exists in the life of every people around the world as the tool for accessing most fields such as internet, banking and travelling (Pasi, 2010). In addition, among the invasion of various information and data through internet have made the English mastery as the priority which cannot be postponed any longer.
Based on the result of preliminary study that the researcher conducted when he was taking Internship in MTsN 2 Kediri on February, year 2018 she found some problems faced by students. When students were writing English, they were difficult to express their ideas. They did not even understand the terms 'content' or 'main idea' of texts. They had many things in mind to tell, but they felt confused how write it down. Students' lack of vocabulary had become a problem to their writing. They tended to repeat the same words several times, and the word choice sometimes was inappropriate with the context they wrote. To resolve those problems, teachers are challenged to 
https://ejournal.uniska-kediri.ac.id/index.php/PROFICIENCY

be more creative in teaching. One of the options is the use online media. Weblog is one of the online media that can be used to teach writing.

Galien and Bowcher (2010) state that weblog is a new tool used for written communication, interaction and available in multiple languages. Weblogs is one of the applications of computer network technology that has been used besides email, electronic journals, web, multimedia, audio, and chatting. According to As'ad (2010, p. 75) weblog is a combination from Web and Log, or now more popular is called a blog or blogging. The term blog means the writing activities in an internet application where the outcome of these writings can be accessed by anyone who has an internet connection and the owner of his/her own blog. Weblog is a web that provides a feature to write and also provide space to exchange comments and peercorrection in the form of grammatical errors. They can give an opinion on his/her friends writing. The teacher can also use a weblog to provide feedback to students so that they can improve their writing. Weblog can help the students improve their writing skills better than before they use it.

This study intends to answer the following questions

1. How is the process of teaching writing of descriptive text at the specific class of the seven grade of MTsN 2 Kediri?

2. How is the response of the students towards the teaching writing of descriptive text at the specific class of the seven grade of MTsN 2 Kediri?

3. How is the teacher's solution of the problems faced by students?

\section{RESEARCH METHOD}

The design of this study was descriptive qualitative to analyze the data. This study was conducted on February $8^{\text {th }}$ to $20^{\text {th }} 2018$ in MTsN 2 Kediri. It is located on Jl. Raya Kanigoro, Jagalan, Kras Kab. Kediri zip code 64172, East Java. The subject of this research are the Staff curriculum, teacher and the students. The teacher and staff curriculum the subject and main role in teaching and learning process. Meanwhile, the students are the object of English teaching.

To collect the data the researcher used instruments such as interview, questionnaire, observation checklist, field note and test. Interview was used to know information from the teacher's side. Meanwhile, the questionnaire, observation checklist and also field note was to collect data about teaching and learning process. The data obtained from observation and interviews were reduced by summarizing, choosing the important information, and classifying them based on the focus. In this research, the data reduced are the results of observation and interview related to the implementation of expert method in teaching and learning process. The procedure of the research comprises 5 steps, they are planning, data collection, data processing, data analysis and conclusion. In planning the researcher prepares the instrument of the research which will help him as the main instrument in collecting the data.

The planning is the starting point to create list of question and activity checklist. Another important part is to finalize the blog design which will be implemented in teaching reading. Data 
https://ejournal.uniska-kediri.ac.id/index.php/PROFICIENCY

collection is done start from right before the teaching to the end of the teaching. The source of data is mainly the studentse participation and their behavior during the class and during online interaction. The way the teacher teaching is also the data that will used to interpret the quality of the teaching. The data processing is the way the researcher reduces the unused data, tabulates the data into categories and makes sure the validity of the data. Data then are analyzed by interpreting them into logical descriptive manuscript and also processed quantitatively. Conclusion is drawn by considering the level of agreement shown in the data which have been analyzed so it can be generalized conclusively.

\section{FINDING AND DISCUSSION}

a. The Process of Teaching Writing of Descriptive Text at Specific Class of MTsN 2 Kediri

Based on the observation can be found that the process of teaching writing at specific class included pre teaching, teaching process, and post teaching. Based on the observation about the pre teaching in writing class was the first, the teacher had to do a greeting. Usually the teacher used salaam in Islamic way because the teacher was religious. Then, the teacher had to check the attendance list. The teacher had always to check the attendance list because it can affect the students' value in the end of semester. After that, she had to do a brainstorming. This activity is doing every meeting. In the teaching process teacher doing scientific approach to make the student active in the class. In every meeting teacher use a blog to support the learning activities in teaching writing of descriptive text. In the post teaching teacher always doing conclusion and give a score to student's work.

\section{b. Students' Response Towards the Teaching}

Feedback is not only given by the teacher to the students. Students can give feedback to their teacher. Feedback can be positive perceptions or negative critiques. However, it is needed by the teacher in order that she can improve the teaching and learning process. It can be the way she teaches, the media used, the evaluation system used, or the activities done in the classroom. Class observation shows that writing class is enjoyable. It is shown by how the teacher opens the class with energetic way, how she builds students' knowledge by raising fun topic related to the subject, and how she makes joke or responds The situation of class helps student to use English to interact using English well, because the field of hospitality of course many foreigners. For students it makes for better job opportunities for them.

Table 2. The response of the students toward the teaching 
https://ejournal.uniska-kediri.ac.id/index.php/PROFICIENCY

\begin{tabular}{|l|l|l|}
\hline \multicolumn{1}{|c|}{ Difficulties } & \multicolumn{1}{c|}{ Sub Focus } \\
\hline $\begin{array}{l}\text { A few students don't know } \\
\text { about the material and less } \\
\text { confident while in front of class }\end{array}$ & $\begin{array}{l}\text { Student like the class, and follow } \\
\text { the class well although they have } \\
\text { difficult }\end{array}$ & $\begin{array}{l}\text { They get tips and tricks } \\
\text { from the teacher }\end{array}$ \\
\hline $\begin{array}{l}\text { Less confident and not familiar } \\
\text { about the vocabulary }\end{array}$ & Enjoy and follow well the class & $\begin{array}{l}\text { They get tips and tricks } \\
\text { from the teacher }\end{array}$ \\
\hline $\begin{array}{l}\text { Being shy in practicing makes } \\
\text { the students get trouble in their } \\
\text { confidences }\end{array}$ & Have the curiosity & $\begin{array}{l}\text { They get tips and tricks } \\
\text { from the teacher }\end{array}$ \\
\hline
\end{tabular}

\section{c. Teacher's Solution of the Problems Faced by Students}

There will be no solution if there is no problem. There will be no improvement in learning if there is no difficulty occurs. Difficulties are found at the first time learner learns the language or when they are learning in the classroom. Solutions are needed in order to minimize or even to stop them. The teacher has explained that the difficulties faced by her were mostly about habit of the students so she uses strategy to overcome her problems.

Media also support learning. Listening to English song or watching English movie and YouTube channel make the students easier to imitate how the grammar and the word. By doing those activities, they apply selfstudy outside the classroom and they will be better than before. Teacher shows the You Tube channel that discuss about descriptive text such as: Fun English lesson, Dikha D wijanarko and Mometrix Academy.

\section{CONCLUSION AND SUGGESTION \\ Conclusion}

The teaching process of descriptive text in MTsN2 Kediri had been supported by sets of equipment in learning such as syllabus, lesson plan, method, media, and material. The response of students toward the teaching process were consist of three terms, they are students' difficulties, and students' perception on teaching learning process. The way of teacher's solution of the problems which are faced by students needed problem identification and solution.

\section{Suggestion}

Based on the research findings of this study in the classroom, the following are suggestions given. The suggestion is addressed to English teacher, students, and other researcher.

\section{a. For English Teachers}

For the English teachers, it is suggested to implementation the use of blog as the media in writing in teaching of descriptive text. The reason is that the use of blog as media in writing descriptive texts can improve their motivation to write. The teacher should guide the students on how to design and to operate the blog. Use representative and interesting teaching media to teach the students will enliven the class and get the students attention. Teacher must be able to create new understanding to the students that learning English is not difficult but it is fun.

\section{b. For Students}

It is suggested to the students to be confidence in expressing everything in English, either in oral or 
https://ejournal.uniska-kediri.ac.id/index.php/PROFICIENCY

in writing. Don't be afraid of making mistakes. When you make mistake it means you are learning but when you are afraid of making mistake then you will never learn. English is not an instant subject to master but it is a kind of habit. Practice to write more then it will help you a lot in improving your skill. In addition, the use of blog could be continued to help all of you in learning writing descriptive text. You can share with other people in the world.

\section{c. For Next Researchers}

For the next researchers, the teaching writing of descriptive text using of blog as the media to the students' writing ability should be used and expanded to the other text types. The blog can also properly be used as the media to write news items texts, report texts, and narrative texts. In addition, it is also suggested for the other researchers to adjust the technique to different levels of education and different settings or places.

\section{REFERENCES}

Arikunto, S. 2006. Prosedur Penelitian sebagai Suatu Pendekatan Praktek. Jakarta: Rineka Cipta.

As'ad, M. 2010.Using Webblogs to Teach Students to Write Recount Texts. In B. Y. Cahyono (Ed), Teaching English by Using Internet Resources (pp.175179). Malang: Penerbit Universitas Negeri Malang.

Brown \& Bailey. 2004. Teaching English as International Language. London: Macmillan Publisher.

Campbell, A. P. 2003. Weblogs for Use with ESL Classes. The Internet TESL Journal, 9 (2): 33 35.

Creame P. and Lea, M. R. 2008. Writing as university, A guide for Students (Third Edit). New York: Mc Graw Hill Companies.
Dieu, B. 2004. Blogs for Language Learning. Essential Teacher, Autumn 1 (4), 26-30.

Galien, P. \& Bowcher, W.L. 2010. 'Using Blogs In ESL/EFL Teaching And TeacherTraining'. Asian EFL Journal.

Kusumawardhani, I. 2012. The Effectiveness of Using Webog to Improve Students' Ability in Writing Recount Texts. Malang: Universitas Negeri Malang.

Mitchell, D. (2003). Thoughts about weblogs in education. Retrieved November 18, 2004, from http://www.teachnology.org/sto ries/storyReader $\$ 150$

Mynard, Jo. 2007. A Blog As A Tool For Reflection For English Language Learners. Asian EFL Journal.

Wyrick, J. 2011. Steps to Writing Well (Eleventh Edition). New York: Lachina Publishing. 